\title{
Efficient Use of Oxy-hydrogen Gas (HHO) in Vehicle Engines
}

\author{
Tamer Nabil
}

Mechanical Engineering Department, Suez Canal University, 51422, Ismailia, Egypt

Corresponding Author Email: tamer_mtc@yahoo.com

https://doi.org/10.18280/jesa.520112

Received: 10 November 2018

Accepted: 7 January 2019

Keywords:
HHO gas, engine performance, gas
emissions

\begin{abstract}
The electrolysis process of water with electrolyte $(\mathrm{NaOH})$ produces oxy-hydrogen $(\mathrm{HHO})$ gas that can be used as an energy source to solve the shortage problem of fossil fuel and reduces the environmental pollution. In this study, HHO dry cell generator was designed, fabricated and tested experimentally to investigate its performance. The hybrid internal combustion engines using $\mathrm{HHO}$ is considered one of the most important studied applications. The engine performance and gas emission are investigated for two different engines; 150CC old engine with carburetor and 1300CC new engine with Electronic Control Unit (ECU). The results recorded the consumption of the fuel is reduced by $14.8 \%$ for $150 \mathrm{CC}$ engine and $16.3 \%$ for $1300 \mathrm{CC}$ engine. HHO gas reduced the emission gases by $33 \%$ and $24.5 \%$ reduction in $\mathrm{CO}$ and $27.4 \%$ and $21 \%$ reduction in $\mathrm{HC}$ for $150 \mathrm{CC}$ and $1300 \mathrm{CC}$ engines respectively.
\end{abstract}

\section{INTRODUCTION}

World demand of energy is very high relative to the supply amount from the traditional sources especially the fossil fuel which is considered the start point of world crisis [1-3]. Increase in fossil fuel consumption results in decreasing its save amount, environmental pollution, global warming with climate change and health thread impacts [4-6]. So researchers studied the fossil fuel usages, applications and claimed it can be reduced by replacing it with another fuels and renewable energy sources or supporting it by secondary fuels as a hybrid system [7-11]. Hydrogen as a hybrid with fossil fuel; gasoline, diesel and LPG, had attention in research field and also commercially (BMW company) due to its combustion advantages [12, 13]. Hydrogen has limited applications due to its explosion nature causing a catastrophe. HHO gas is a mixture of hydrogen and oxygen gases with theoretical ratio 2:1 produced from water electrolysis process. HHO gas used in the last years as a hybrid with internal combustion engine fuels instead of hydrogen due to it is safer in use with good combustion properties and easy to be created onboard. Oxyhydrogen, hydroxyl, $\mathrm{H}_{2} / \mathrm{O}_{2}$, Rhodes gas and Browns gas, all these are alternative names for HHO gas. Oxy-hydrogen gas is considered a cornerstone in reducing the fuel consumption and at sometimes completely dispensed with as a cradle energy source. HHO gas can be obtained from dry cell and wet cell through electrolysis process [14]. Wet cell designed as plates submerged in water, while in dry cell the water runs through the plate. Wet cells have higher gas production but it required more current nevertheless dry cell more adapted to operate with moving engines since the electrolyte volume content is smaller and sealed [15].

Electric power (amperage and voltage), metal plates (charged terminals and neutrals); number, area and material, electrolyte type and percentage; these are main components of $\mathrm{HHO}$ generator responsible for the electrochemical ionization reactions and splitting the bonds in $\mathrm{H}_{2} \mathrm{O}$ molecule to form
HHO gas [16, 17]. All researchers in the field of hybrid vehicle engines with $\mathrm{HHO}$ gas claimed lower fuel consumption, higher engine performance and lower gas emission than individual gasoline or diesel engines [18-27].

By this way, Wang et al. [28] improved the performance of gasoline engine by hydrogen-oxygen mixture addition. They compared the addition of hydrogen and hydroxygen with three volume fractions $(0,2 \%$ and $4 \%$ with excess air ratio variation on the engine performance and engine emission at $1400 \mathrm{rpm}$ and a MAP of $61.5 \mathrm{kpa}$ under lean conditions. After adoption of ECU, the blending of hydroxygen with gasoline engine results in higher percentage of the thermal efficiency, the brake means effective pressure and NOx emission than the conventional engine and hybrid gasoline with hydrogen engine at lean conditions with lower $\mathrm{CO}$ emission.

EL-Kassaby et al. [29] designed, optimized and fabricated HHO dry cell. They studied the effect of variation of the catalyst type and its quantity. They used two catalyst materials, sodium hydroxide and potassium hydroxide. The effect of HHO gas on the performance of Skoda Felicia 1.3 GLXi (1300CC) engine and the exhaust gas emissions was studied. They produced $181 / \mathrm{h}$ of $\mathrm{HHO}$ gas from their designed generator. The engine performance enhanced after HHO gas addition with fuel such that $10 \%$ increase in thermal efficiency and $34 \%, 18 \%, 14 \% 15 \%$ reduction in fuel consumption, carbon monoxide, hydrocarbons, and nitrogen oxides.

Vemula [30] investigated the performance and emission of $149 \mathrm{cc}$, 4stroke spark ignition single cylinder engine with HHO gas at low engine speeds from 700 to $1500 \mathrm{rpm}$. Specific fuel consumption and total fuel consumption of the engine are decreased from $5 \%$ to $12 \%$ with addition of HHO gas. Brake thermal efficiency increased by 5-10\%. Carbon monoxide decreased by $20 \%$ and NOx decreased by $62 \%$. Rajasekaran et al. [31] investigated $150 \mathrm{CC}$ single cylinder engine fueled by gasoline engine and liquefied petroleum gas. This investigation was extended to introduce $\mathrm{HHO}$ gas to these engines. In both experiments the incorporation of $\mathrm{HHO}$ gas 
results in decrease in fuel consumption and emissions. Experimental results show introducing $\mathrm{HHO}$ to gasoline and LPG engines results in decrease in fuel consumption by $9.6 \%$ and $15.7 \%$, CO concentration reduction by $27.5 \%$ and $52.1 \%$. Sunil Raj et al. [32] studied a single cylinder air cooled $100 \mathrm{CC}$ spark ignition petrol engine conducted by HHO gas. They observed smooth and stable operation of the engine with HHO gas and a reduction in carbon monoxide and hydrocarbons percentage.

Musmar and Al-Rousan [33] studied the gasoline engine emissions with effect of $\mathrm{HHO}$ gas. The tested engine was Honda G200 (197CC) and the measurements recorded at different speed. Gasoline engine hybrid with $\mathrm{HHO}$ gas resulted in increase of engine efficiency, reduction of $\mathrm{NO}$ and NOx about $50 \%$, reduction of $\mathrm{CO}$ concentration about $20 \%$ and fuel consumption reduction between $20 \%$ to $30 \%$. Al-Rousan [34] alone studied the same engine with two different sizes of HHO generators ( $B$ and $C$ types). He defined the cell size as a ratio of cell surface area and piston area with optimum ratio $20: 1$, and the needed water volume is 1.5 times the engine capacity.

CI engines integrated with $\mathrm{HHO}$ gas was studied by Yilmaz et al. [35]; their results recorded an increase in torque by $19.1 \%$, a reduction in CO and Hydrocarbons (HC) emissions percentage by $13.5 \%$ and $5 \%$ respectively and a reduction in specific fuel consumption by $14 \%$. Karagöz [36] studied the diesel engine response to the introduction of different levels of hydrogen $[0 \%, 40 \%$ and $75 \%]$ into intake manifold of engine. The tested diesel engine was single cylinder with volume $1163 \mathrm{CC}$ and compression ratio 14.7 at $1300 \mathrm{rpm}$ engine speed and full load. Increasing hydrogen percentage results in improvement of break thermal efficiency by $1.26 \%$ and $2.1 \%$. The percentage of decrease carbon monoxide $25 \%, 60 \%$ and hydrocarbons $30 \%, 60 \%$ by using hydrogen as a secondary fuel were; also unusual decrease up to $70.7 \%$ of smoke emission was obtained at $75 \%$ hydrogen concentration.

After these reviews, this work aims to shed the light on $\mathrm{HHO}$ gas through the design and fabrication of different models of $\mathrm{HHO}$ gas dry generator. Also, enabling efficient, affordable and robust use of $\mathrm{HHO}$ gas generator for vehicle petrol engines (old and new).

\section{EXPERIMENTAL SETUP AND PROCEDURES}

\subsection{HHO gas characteristics}

HHO gas has the nature of implosion due to its atomic structure, when a pure gas burned consequently the vacuum is immediately formed causing this implosion. Flame temperature of $\mathrm{HHO}$ gas varied according to the receipting materials. Open air gas flame temperature about $135{ }^{\circ} \mathrm{C}$, applying the gas flame to the aluminum and brick causes temperature to reach up to $702{ }^{\circ} \mathrm{C}$ and $1704{ }^{\circ} \mathrm{C}$ respectively. HHO gas flame is awfully directional and the molecular structure of some materials can be changed by HHO gas influence. Auto-ignition of $\mathrm{HHO}$ gas occurs at about $570^{\circ} \mathrm{C}$ at STP. The theoretical energy level of HHO gas has about $60,000 \mathrm{Btu} / \mathrm{lb}$. HHO gas is odorless, colorless and lighter than air; it does not need oxygen for burning meanwhile the gas internally contains the oxygen. Due to the wide range of flammability and high burning velocity (1000 times of petrol vapor) the HHO gas permits the use of lean air-fuel mixture with acceptable emissions and combustion efficiency. It has abnormal adsorption to gases, liquids and solids, making it to be used as an additive to other fuel to improve the environmental quality [37].

\subsection{General design and constructional parameters of HHO generator}

Generally, HHO dry generator is composed of metal plates, stainless steel is preferred due to its good electrical, thermal and physical properties, specifically stainless steel $316 \mathrm{~L}$ is used in this study, with certain number and dimension determined according to the design and the application. Stainless steel is anti-corrosive metal with melting point 1375 $1400{ }^{\circ} \mathrm{C}$.

The plates are connected to the electric DC power source such that, for one stack generator, one plate has positive charge (anode), one plate has negative charge (cathode) and the reminders are neutral. Numbers of neutral plates is determined according to the design in order to divide the source voltage equally between cells with reasonable value.

Every two successive plates formed a closed compartment with the aid of rubber gasket. The rubber gaskets ensure a good sealing of any plate to touch the neighbor plate and guarantee the water and gas existence inside the generator. Rubber has thickness tolerance under pressure force with final thickness $3 \mathrm{~mm}$ is reasonable to satisfy a convenient current resistance and suitable space permitting the $\mathrm{HHO}$ gas to escape freely in the required direction.

The plates have down small holes for equalizing the water level in the cells and to permit the electrons to flow under voltage drop with small friction and heat generated. Also there are upper large holes permitting the gas to vent, these hole in uppermost to increase the surface area of contact with water and to speed up the gas out. If the plate design has a rectangular shape, then the smaller edge length is oriented to be the path of HHO gas.

Generator has accessories: two acrylic end cover plates with thickness $12 \mathrm{~mm}$ one of them has inlet water hole and the other has outlet gas hole, bolts, washers, nuts, fittings, bubbler, connectors, non-return valve, hoses and tank. The tank ensures continuous feeding of electrolyte to the generator that guarantee cooling of the generator. A bubbler is a container partially filled with water and $\mathrm{HHO}$ gas is fed through its bottom, and obligatory rises through the water before continuing its passage. The bubbler is important to avoid backfires from reaching the electrolyzer and is required for drying and purification of $\mathrm{HHO}$ gas from water vapor before reaching to the power applications [38]. Non-return valve between the electrolyzer and bubbler is safety essential in the backfire case.

\subsection{Operational parameters of HHO generator}

According to the required amount of $\mathrm{HHO}$ gas and available electric power source the number of cells and stacks are determined; also the effective area of the plates is calculated. The number of cells and the electrolyte concentration has direct effect on cell voltage. The voltage of each cell can be calculated as the source voltage divided by the number of cells (from reviews; Faraday 1.24V, Brown 1.48V and Boyce 2-3V for one cell) [38]. According to Boyce approximated $2 \mathrm{~V}$ value for each cell make the generator working conditions are appropriated without heating.

The gap between plates and the operation cell temperature 
must be taken into consideration when cell amperage was evaluated. Pure water in default has a high resistance to current flow so this resistance must be decrease by adding certain amount of electrolytes. The concentration of the electrolyte in water highly affect on the cell amperage determination. During the operation, if the electrolyte concentration slight increases due to heat generation consequently the current increases in response.

The quantity of HHO gas depends on the water efficiency to pass the current and the amount of current succeeded to travel through the plate surface area. Faraday highlight, each square inch of plate surface area can support 0.54 amps of current. Faraday's first law to calculate the theoretical maximum production of $\mathrm{HHO}$ gas [38];

$\mathrm{V}=\frac{\mathrm{RITt}}{\mathrm{zFP}}$

where, $\mathrm{V}$ is volume of gas (1), $\mathrm{R}$ is ideal gas constant = 0.0820577 l.atm/(mol.K), $\mathrm{I}$ is current $(\mathrm{A}), \mathrm{T}$ is temperature $(\mathrm{K})$, $\mathrm{t}$ is time (s), F is Faraday's constant $=96485$ Coulombs $/ \mathrm{mol}, \mathrm{P}$ is ambient pressure (atm) and $\mathrm{z}$ is number of excess electrons ( 2 for $\mathrm{H}_{2}, 4$ for $\mathrm{O}_{2}$ ).

\subsection{Experimental work on HHO generators}

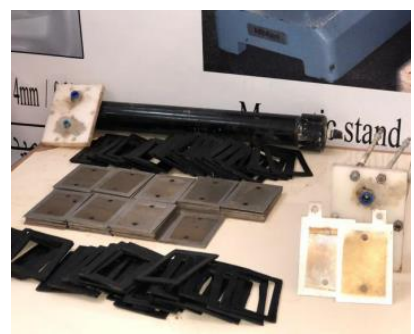

a- Materials required for generators construction

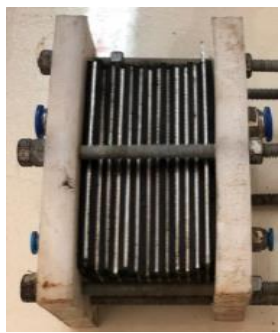

c- 13 plates, 2 stacks $(6$ cells)

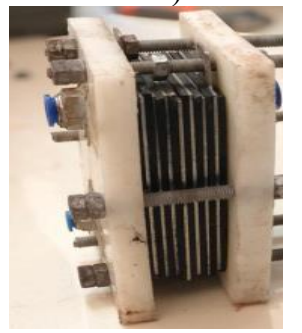

e- 7 plates, 1 stack (6 cells)

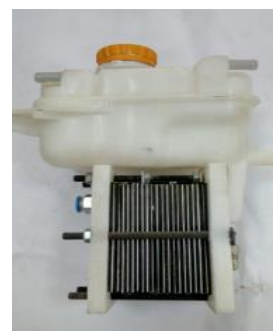

b- 19 plates, 3stacks (6cells)

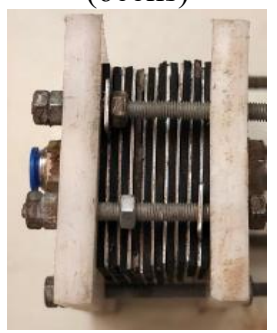

d- 9 plates, 1 stack (8cells)

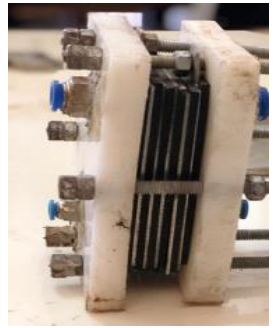

f- 5 plates, 1 stack (4 cells)
Figure 1. Photograph of different HHO generators and construction materials

The design of HHO generators varies according to the application, required energy from the output $\mathrm{HHO}$ gas, and available electrical power. Every design has limited operational conditions and performance according to the efficiency of the electrolysis process. Number of plates, plates metal, plates dimensions, type of electrolyte and its concentration and distance between plates; all these design parameters professionally affects the efficiency, durability and the productivity of $\mathrm{HHO}$ gas generators. The operational parameters, pressure, temperature, amperage and voltage, must be taken into consideration. Before installation of the generator in any application its performance must be investigated individually. In this study, different generators are designed, fabricated and tested; 5, 7, 9 plates single stack generators, 13 plates two stacks ( 2 negative and 1 positive plates) generator and 19 plates 3 stacks ( 2 negative and 2 positives plates) also 7 plates single stack generator was tested with different electrolyte concentrations (sodium hydroxide, $\mathrm{NaOH}$ ), as shown in Figure 1. All these models were fabricated generally without targeted application but to investigate the behavior of HHO generators and to evaluate their performance to obtain the finger print of any generator. In each case the amount of HHO gas, amperage and temperature were measured. Experimental measurements required; voltmeter, K-type thermocouple, clamp meter, graduated cylinder, bottle and stopwatch. The amount of produced $\mathrm{HHO}$ gas is measured manually using water displacement from bottle in the graduated cylinder and stopwatch.

The plates are fabricated from stainless steel 316L with dimension $140 \times 100 \times 1 \mathrm{~mm}$. According to the design and available power the number of active plates, neutral plates, and number of stacks are determined. The thickness of the used rubber gasket is $4 \mathrm{~mm}$ between each two mean plates and between the extreme plates and the acrylic cover. This thickness with tightening the cell by nails and nuts was decreased to $3 \mathrm{~mm}$. $12 \mathrm{~V}$ battery was used as a power source. According to Bob Boyce $2 \mathrm{~V}$ average for each cell is a good electrical pressure value for durable working conditions. Experimental test of 7 plates ( 6 cells) generator with different electrolyte molarity is performed firstly to choose the most suitable electrolyte concentration of the remaining experiments. From the experimental results electrolyte molarity 0.125 shows good efficiency so it is applied to all generators. The average working time of each experiment is approximately one hour. The experimental results are shown in Table 1. The experimental set-up and showed results turn out the reader for actually figuring out the pros and cons of the adopted systems.

From the experimental measurements shown in Table 1, at fixed cell voltage and plate area, the amperage is controlled by Sodium Hydroxide (electrolyte) concentration.

It can be observed, a directly proportion relationship between the electrolyte temperature and the cell amperage, which is considered generator obstacle. The increased current through the cell causes the generator become hotter which is a closed loop results in bad efficiency [38]. The electrolyte heating causes the increase of the electrolyte concentration with time as the amount of $\mathrm{NaOH}$ is constant while the amount of the water reduces due to evaporation. This problem can be solved by reducing the concentration of $\mathrm{NaOH}$ in water at starting such that after certain working time the electrolyte temperature reached its maximum value and the designed current is reached. This solution is simple but the amount of HHO gas at starting is very low till reached the required operating conditions, also the determined electrolyte concentration is evaluated by trials. 
Table 1. Performance of different $\mathrm{HHO}$ generators and effect if molarity variations

\begin{tabular}{ccccccc}
\hline Item & $\begin{array}{c}\text { Current } \\
(\mathbf{A})\end{array}$ & $\begin{array}{c}\text { Power } \\
(\mathbf{W})\end{array}$ & $\begin{array}{c}\text { Gas production } \\
(\mathbf{m l} / \mathbf{m i n})\end{array}$ & $\begin{array}{c}\text { MMW } \\
(\mathbf{m l} / \mathbf{m i n} / \mathbf{W})\end{array}$ & $\begin{array}{c}\text { Molarity } \\
(\mathbf{M})\end{array}$ & $\begin{array}{c}\text { Temp. } \\
\left({ }^{\circ} \mathbf{C}\right)\end{array}$ \\
\hline 5 plates & $4.2-4.4$ & $50.4-52.8$ & $194-203$ & 3.84 & 0.125 \\
7 plates & $3.7-3.9$ & $44.4-46.8$ & $179-189$ & 4.03 & $34-39$ \\
9 plates & $3.6-3.8$ & $43.2-45.6$ & $213-246$ & $4.9-5.3$ & 0.125 \\
13 plates, 2 stacks & $4.8-5.1$ & $57.6-61.2$ & $469-513$ & $8.1-8.3$ & 0.125 \\
19 plates, 3 stacks & $5.6-5.9$ & $67.2-70.8$ & $551-585$ & $8.19-8.26$ & 0.125 \\
7 plates generator at different & $3.7-3.9$ & $44.4-46.8$ & $179-189$ & 4.03 & $30-37$ \\
molarity & $3.8-4.2$ & $45.6-50.4$ & $180-199$ & $3.9-3.95$ & 0.125 \\
& $4.3-5.1$ & $51.6-61.2$ & $205-245$ & $3.97-4$ & $31-41$ \\
\end{tabular}

Table 1 shows, from point of view of gas productivity to used power ratio, 13 plates two stacks with 0.125 electrolyte molarity had been preferred. The generator with 5 plates has abnormal behavior due to the cell voltage has $3 \mathrm{~V}$ which is very large value compared to the standard cell voltage that results in high temperature and amperage. The ambient temperature is considered a main factor in determining the resistance of the water so it was measured in all tests.

The plate area must be optimized such that the grater area means the grater produced gas due to the enlargement in the probabilities of bubbles escaping from the plates but the greater current is required that causing high power requirement and heating the electrolyte. It is suggested that the face area of the plates between 2 to 4 in $^{2}$ per ampere of current [38]. The electrolyte heating is a bad effect as it drives a water vapor mixes with the gas and is fed to the engine, diluting gas concentration and lowering the waited power from the hybrid engine with HHO gas. In the electrolysis process the liquid water transforms to $\mathrm{HHO}$ gaseous state through a phenomenon neither evaporation nor separation and with less energy.

\subsection{HHO gas generator corrosion}

Distilled water has high current flow resistance, so if it used alone as a working fluid in the electrolysis process no gas will be produced. However, catalyst materials (electrolytes) must be added to the distilled water to increase its conductivity. The additive catalyst materials must be carefully chosen to avoid any undesirable effects. Salts, as one of the proposed additive to water, enhance the electrolysis rate but results in corrosion and chlorine gas. The corrosion is clearly shown if a tap water was used instead of distilled one, and its effect is tremendous if the materials of generator plates can be corroded or with low grade. Figure 2 shows the cell corrosion after working 28 hours under potential voltage $110 \mathrm{~V}$ (to accelerate the corrosion effect), tap water with salt as a catalyst and low grade stainless steel plates. Many substances can be used as a catalyst of the water in the electrolysis process but large numbers of them have disagreeable influences.

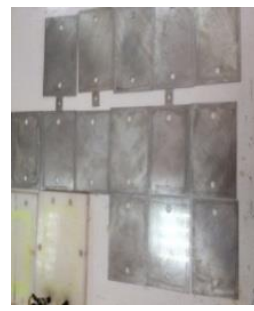

(a) Plates before corrosion

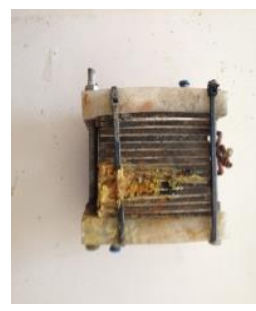

(b) Generator after corrosion

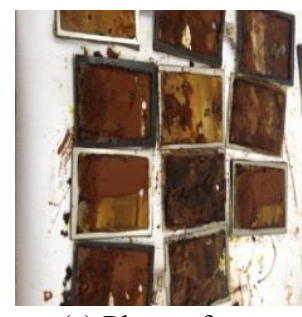

(c) Plates after corrosion
Sodium hydroxide, $\mathrm{NaOH}$ or lye, and potassium hydroxide, $\mathrm{KOH}$, are the best additives choices as catalysts. The percentage of the catalyst is a main factor in evaluating the cell current. There is a boundary to this concentration percentage, the gas production increases with catalyst concentration until the limit $28 \%$ (weight). Subsequently any increase in the concentration produces a reduction in gas production. Every time of experimental preparations, start with water, add the catalyst slowly, stirring and let the mixture to cool between the additions [39].

\subsection{HHO gas quantifications}

The exhaust gases from the experimental tests were analyzed in mass spectrometer. HHO gas is a combustible gas composed of a mixture of hydrogen and oxygen gases with volumetric ratio (stoichiometric) $66.66 \%$ hydrogen to $33.33 \%$ oxygen $(2 / 3: 1 / 3)$. HHO gas has abnormal behavior since it is not composed of only hydrogen and oxygen but has additional heavier species. Experimentally, HHO specific weight is $12.3 \mathrm{~g} / \mathrm{mol}$ but numerically it has $11.3 \mathrm{~g} / \mathrm{mol}$ with $8.8 \%$ difference in specific weight corresponds to $60.79 \%$ hydrogen $\left(\mathrm{H}_{2}, 2\right.$ atomic mass unit (amu)) to $30.93 \%$ oxygen $\left(\mathrm{O}_{2}, 32\right.$ atomic mass unit $\left.(\mathrm{amu})\right)$ and other heavier, high reactive and stable species resulted from bonding of $5.87 \%$ hydrogen and $2.94 \%$ oxygen [40].

\subsection{Experimental work on hybrid internal combustion engines and $\mathrm{HHO}$ gas}

The unconventional added fuel for the traditional internal combustion engines fuels speaks to lessening fuel utilization and toxin outflows emission created by these engines. This part of study aims to boost engines performance and to scale back fuel consumption by combination the traditional gasoline engines with $\mathrm{HHO}$ gas at the engine intake. This application of $\mathrm{HHO}$ gas is considered one of the most important applications.

The experiments are performed on two engines; Dayune $150 \mathrm{CC}$ as old engine and Mitsubishi Lancer 1.3GL as new one, the engines detailed specifications are shown in Table 2. In order to show the effect of HHO gas, the performance of engines with and without $\mathrm{HHO}$ generators are evaluated and compared under constant load conditions with engines speed variation from $1100 \mathrm{rpm}$ to $2500 \mathrm{rpm}$ for $150 \mathrm{CC}$ and from $1250 \mathrm{rpm}$ to $2500 \mathrm{rpm}$ for $1300 \mathrm{CC}$. Bob Boyce prescribed the optimum amount of oxy-hydrogen varied between 0.25 and 0.5 liter per minute for each $1000 \mathrm{cc}$ of engine [38]. So, the tested engines capacity required $0.0375-0.075 \mathrm{l} / \mathrm{min}$ and $0.325-0.65 \mathrm{l} / \mathrm{min}$ of $\mathrm{HHO}$ gas for $150 \mathrm{CC}$ and $1300 \mathrm{CC}$ gasoline engines respectively. From investigations and several trials, Bob Boyce prescription of the optimum amount of oxy-

Figure 2. Photos of generator corrosion 
hydrogen required for each engine is valid for large engines volume and not applicable to small engines. So, the required generators are 9 plates $(140 * 100 * 1 \mathrm{~mm})$ one stack for $150 \mathrm{cc}$ and 13 plates two stacks each stack 7 cells for $1300 \mathrm{cc}$ $(140 * 100 * 1 \mathrm{~mm})$

Table 2. Engines specifications

\begin{tabular}{|c|c|c|}
\hline & Dayun engine & $\begin{array}{c}\text { Mitsubishi Lancer } \\
\text { engine }\end{array}$ \\
\hline Engine type & $\begin{array}{l}\text { Single cylinder, 4- } \\
\text { stroke, air-cooled }\end{array}$ & $\begin{array}{c}4 \text { cylinders, } 4- \\
\text { stroke, water-cooled }\end{array}$ \\
\hline Start type & Electric \& kick & Electric \\
\hline $\begin{array}{c}\text { Engine } \\
\text { displacement (cc) }\end{array}$ & $150 \mathrm{CC}$ & $1298 \mathrm{CC}$ \\
\hline Ignition system & CDI & $\begin{array}{l}\text { Naturally aspirated } \\
\text { petrol } 4 \mathrm{G} 13\end{array}$ \\
\hline Bore & $0.062 \mathrm{~m}$ & $0.071 \mathrm{~m}$ \\
\hline Stroke & $0.0495 \mathrm{~m}$ & $0.082 \mathrm{~m}$ \\
\hline Clearance volume & $2.23168 \times 10^{-5} \mathrm{~m}^{3}$ & $\begin{array}{l}\text { 9.5:1 compression } \\
\text { ratio }\end{array}$ \\
\hline No. of gears & 5 & $\begin{array}{l}5 \text { speed manual } \\
\text { gearboxes }\end{array}$ \\
\hline $\begin{array}{c}\text { Cylinder } \\
\text { Arrangement }\end{array}$ & Single cylinder & straight \\
\hline Maximum power & $\begin{array}{c}8.5 \mathrm{~kW} \\
@ 7500 \mathrm{rpm}\end{array}$ & 55kW@6000rpm \\
\hline Maximum torque & $\begin{array}{c}11.5 \\
\text { Nm@6000rpm }\end{array}$ & 108Nm@3000rpm \\
\hline Fuel tank capacity & $\begin{array}{l}13 \mathrm{~L} \text { with } 20 \mathrm{~W} 50 \\
\text { fuel type }\end{array}$ & $\begin{array}{c}\text { 50L, EFi fuel } \\
\text { system }\end{array}$ \\
\hline
\end{tabular}

After the generators have been installed with engines, the average cell efficiency was recorded at different engine speed and electrolyte concentrations. The cell efficiency depends on the cell productivity of $\mathrm{HHO}$ gas with certain calorific value as cell output energy and the time of induced electrical power as cell input energy. Figure 3 shows the effect of 1300CC tested engine speed (1500 and 2000rpm) and catalyst concentration $(5,10$ and $20 \mathrm{~g} / \mathrm{L})$ variations on average cell efficiency. Catalyst concentration $5 \mathrm{~g} / \mathrm{L}$ of $\mathrm{NaOH}$ gives higher efficiency at different engine speeds.

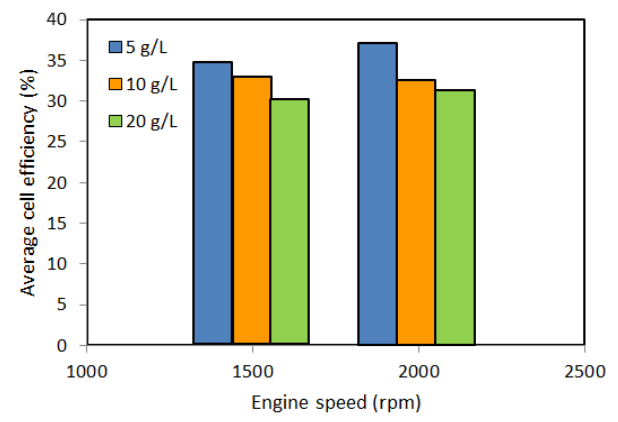

Figure 3. Average cell efficiencies with using different $\mathrm{NaOH}$ concentrations at different engine speeds

The installation of the generators with engines have certain precautions such as, chose the place that exposed to air cooling and away from heat engine and rotating parts as shown in Figure 4. HHO gas directed to engine through pipe fixed at the air intake manifold. Safety precaution requires connection of flash back arrestor in the way of $\mathrm{HHO}$ gas from the generator to the air manifold of engine to separate the engine and generator in case of flash back. The two engines are controlled by $12 \mathrm{~V}$ battery and according to the voltage distribution principle each compartment of $150 \mathrm{CC}$ and $1300 \mathrm{CC} \mathrm{HHO}$ generators has $1.5 \mathrm{~V}$ and $1.71 \mathrm{~V}$ respectively. According to Bob Boyce the average voltage of any compartment must be around $2 \mathrm{~V}$ for optimum and durable operation. During the engines operation the battery alternator changes the voltage by range from 13.5 to $14 \mathrm{~V}$. By this way, the compartment voltage becomes $1.71 \mathrm{~V}$ and $1.96 \mathrm{~V}$ respectively which are reasonable.

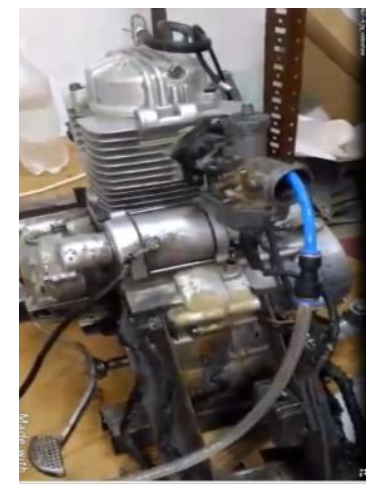

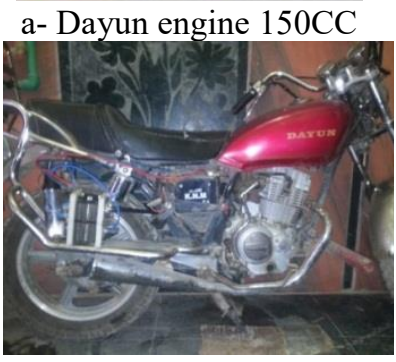

c- Dayun 150CC

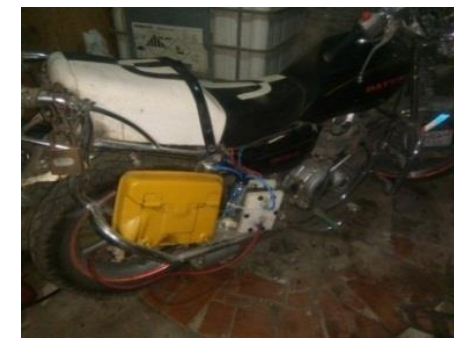

b- Dayun $150 \mathrm{CC}$

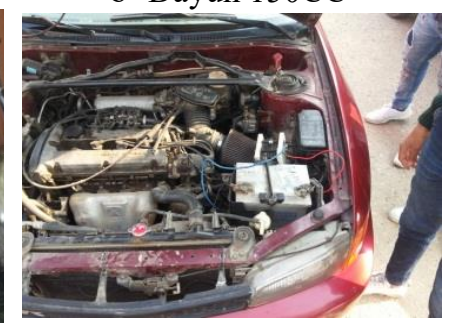

d- Mitsubishi Lancer 1300CC
Figure 4. Photograph of the experimental setup of different engines with HHO generators

HHO gas generator can work with old vehicle engines operated by carburetor and with modern vehicle engines operated with computer (ECU). The performance of old vehicle engine enhanced immediately with $\mathrm{HHO}$ gas incorporation with simple modification which is the changing of the jet to a smaller diameter. Whenever, in modern vehicles the system needs a lot of modifications to reasonably work with $\mathrm{HHO}$ gas. Due to the combustion advantages of HHO gas, it causes the improvement of gasoline burning in the engine cylinder results in increase in engine performance. The vehicle computer is guessing the same amount of oxygen in the exhaust gases and increases the fuel rate to reach its normal stabilized operation conditions. By this way HHO gas has no improvement to the engine performance waiting the adjustment of the vehicle computer. So, vehicle ECU is connected to oxygen sensors to control the fuel consumption. The range of the oxygen sensor $0.2-1 \mathrm{~V}$ (low value means the mixture is too lean) depending on the amount of oxygen in the exhaust gases is transmitted to ECU to adapt the fuel rate. So, after HHO installation, the voltage output from the oxygen sensor must be changed.

There are some additional accessories must be incorporated with ECU and oxygen sensors to ensure the effect operation of $\mathrm{HHO}$ gas as shown in Figure 5. Mass air flow sensor (measure the amount of air in the intake and send the signal to ECU to introduce fuel according to the corresponding air to fuel mixture ratio), Manifold Absolute Pressure sensor (measure the vacuum pressure in the intake and send the signal instantaneously to ECU according to this value), these sensors 
help the engine to operate properly and must be adapted in case of $\mathrm{HHO}$ gas to reduce the fuel consumption, influence ignition timing and increase the engine performance. In some cases, researchers preferred using Electronic Fuel Injection Enhancer (EFIE) to emphasize the engine modifications and to ensure the reduction of fuel consumption with $\mathrm{HHO}$ gas but it increase the system complications. As shown in Figure 5, ECU has a great control function to save the consumed fuel and to increase the mileage with HHO gas. The data of these sensors are recorded during the experiments to show the state of fuel consumption and the effect of $\mathrm{HHO}$ gas.

In all tests, the engine performance was recorded with and without HHO gas and compared. Code reader diagnostic scanner tool, tachometer (for engine speed measurement), Ktype thermocouple (for exhaust gas temperature measurement), voltmeter, clamp meter and flow meter are equipment used in experimental work. In all experimental tests, for both engine cases, the ambient and engine temperatures are normal, the engines were at idle states and the code reader diagnostic scanner tool reading had no problem code.

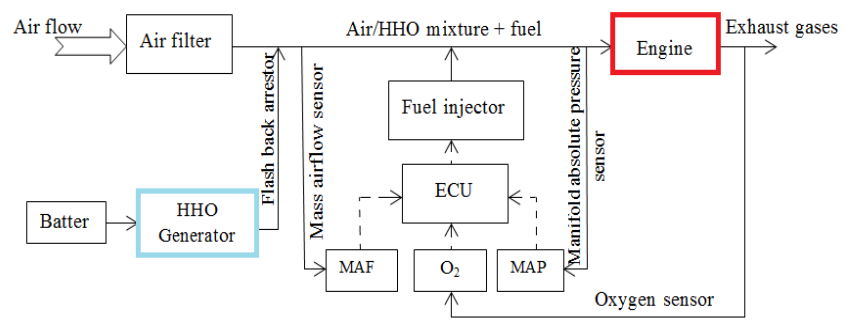

Figure 5. Schematic drawing of modern gasoline engine with HHO generator

\section{RESULTS AND DISCUSSIONS OF ENGINES PERFORMANCE WITH HHO GAS}

\subsection{Engine performance}

Figure 6 shows the motor brake power efficiency at constant load and different engine speeds. Since HHO gas has calorific value higher than gasoline, the measurements recorded a growth of the engine brake efficiency with $\mathrm{HHO}$ gas generator $17.9 \%$ for $150 \mathrm{CC}$ and $22.4 \%$ for $1300 \mathrm{CC}$. This enhancement resulting from the heat energy liberated from HHO burning, simplified the break of bonds of gasoline molecules, resulted in high combustion efficiency. This complete, efficient and smooth combustion in addition to the piston can safely complete its stroke closer to top dead center (TDC) were the main reasons for this engine break efficiency development with $\mathrm{HHO}$ gas. The resulted high power from complete combustion turned into obvious mechanical torque. At high engine speeds, for two engine cases, there are small differences of brake efficiency due to the saturation state of $\mathrm{HHO}$ generators has been reached, threshold gas productivity, as the amperage increased the HHO gas productivity amount still constant.

Since thermal efficiency depends on the brake efficiency and the heat input also it's an indication of combustion efficiency. Figure 7 shows the enhancement of thermal efficiency was clear for engines with $\mathrm{HHO}$ gas. The recorded enhancements in thermal efficiencies were $15.7 \%$ for $150 \mathrm{CC}$ and $22.4 \%$ for $1300 \mathrm{CC}$. This development indicates complete combustion and reduction of heat input due to the great energy content of the $\mathrm{HHO} /$ air/fuel mixture. Also, shorter combustion time and high flame speed results from HHO gas addition to the gasoline engines results in high thermal efficiency and a reasonable amount of combustion energy was transferred to useful power. One of the supreme advantages of HHO gas, it increases the octane rating of any fuel added with it and so enhances the characteristics of the low grade fuel and delays its ignition to approach TDC in safe similar to the high octane fuel.
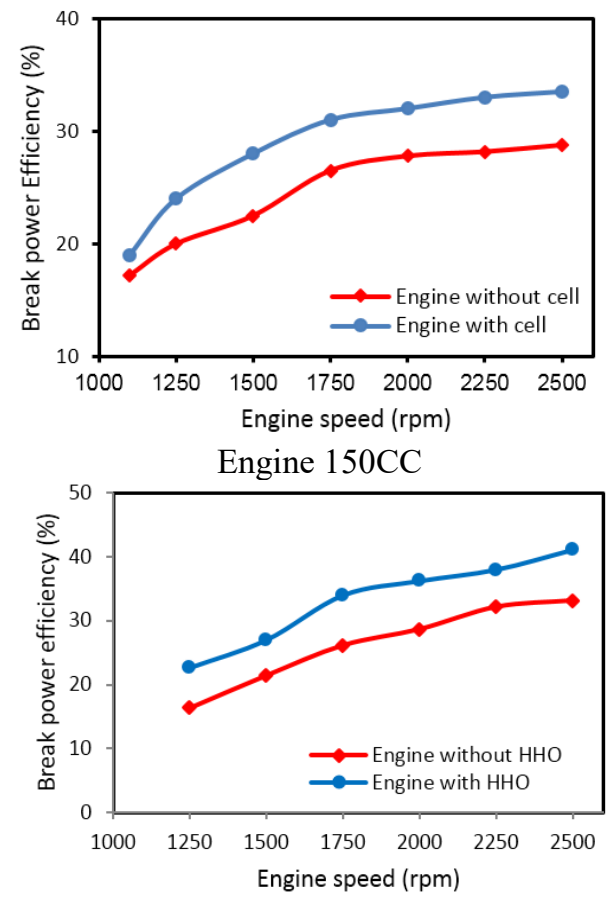

Engine 1300CC

Figure 6. Break power efficiency (\%) versus engine speed (rpm) with and without $\mathrm{HHO}$
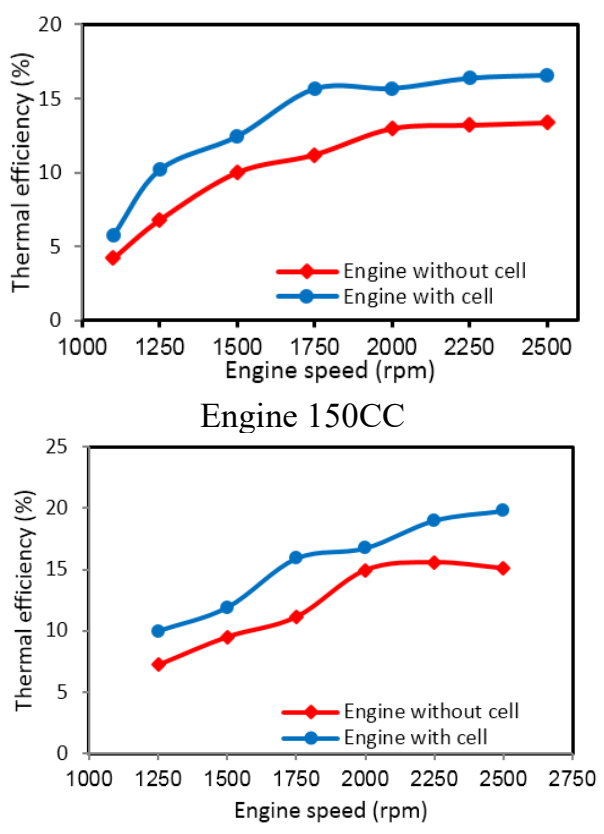

Engine 1300CC

Figure 7. Thermal efficiency (\%) versus engine speed (rpm) with and without $\mathrm{HHO}$

Figure 8 shows the fuel consumption at different engine 
speeds with a reduction in the consumed fuel amount with addition of $\mathrm{HHO}$ gas to the engines. $\mathrm{HHO}$ gas helps the engine to reach the required power and mileage with smaller fuel amount. The reduction in fuel is approximately $14.8 \%$ for $150 \mathrm{CC}$ and $16.3 \%$ for $1300 \mathrm{CC}$. Figure 9 shows, as the engine speed increases the specific fuel consumption decreases while for engines with HHO gas this decrease is obvious. The values of specific fuel consumption for engines with $\mathrm{HHO}$ gas are lower than for the same engine without HHO gas at the same engine speed.
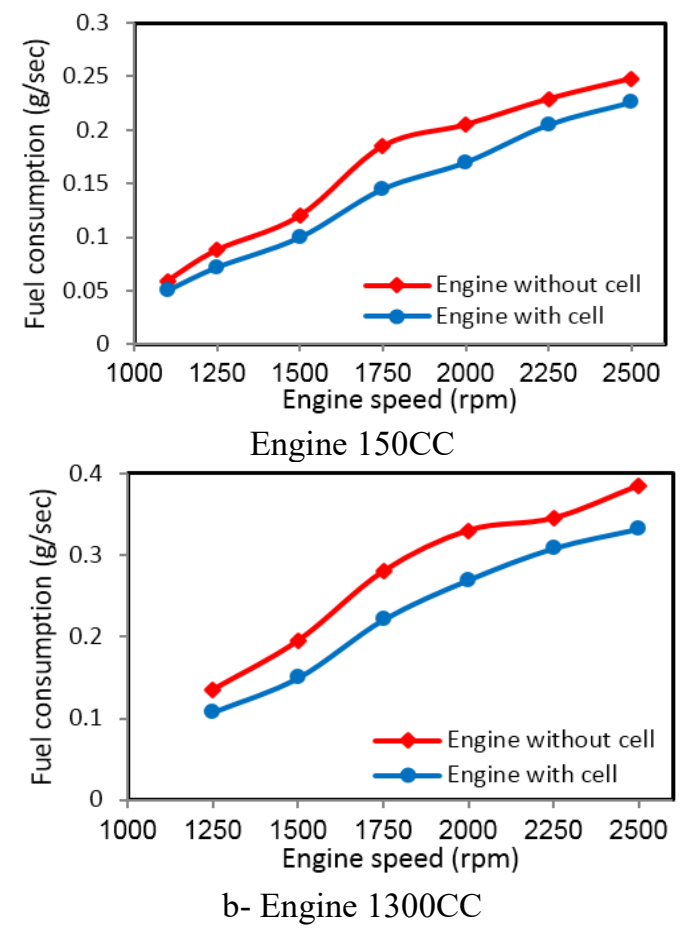

Figure 8. Fuel consumption $(\mathrm{g} / \mathrm{sec})$ versus engine speed (rpm) with and without $\mathrm{HHO}$
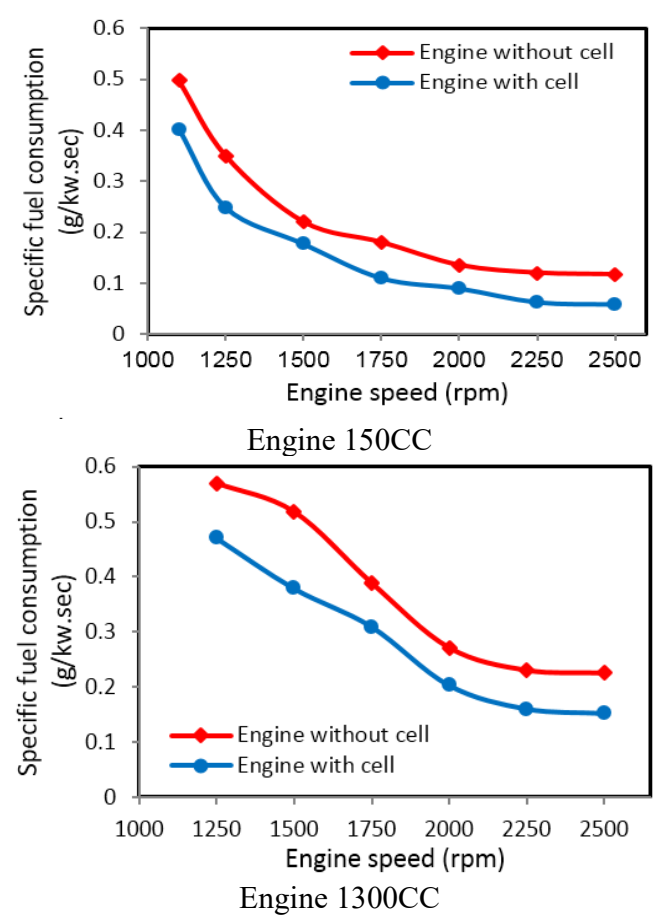

Figure 9. Specific fuel consumption (g/kw.sec) versus engine speed (rpm) with and without HHO
In all tests, the temperature of the engines exhaust gases increases as the engines speeds increase nevertheless for engines with $\mathrm{HHO}$ gas the temperature is lower than the conventional engine. Figure 10 records the exhaust gas temperature and explains the reduction in case of engines with $\mathrm{HHO}$ gas. In each cases, as the engine speed increases the exhaust gas temperature increases but with lesser amounts in case of HHO gas utilization due to the enhancement in the combustion with the formation of $\mathrm{H}_{2} \mathrm{O}$ as a combustion result that helps in decreasing the exhaust gas temperature. Also the presence of HHO reduces the consumption amount of the fuel, lean mixture phenomenon, causing a drop in the temperature.
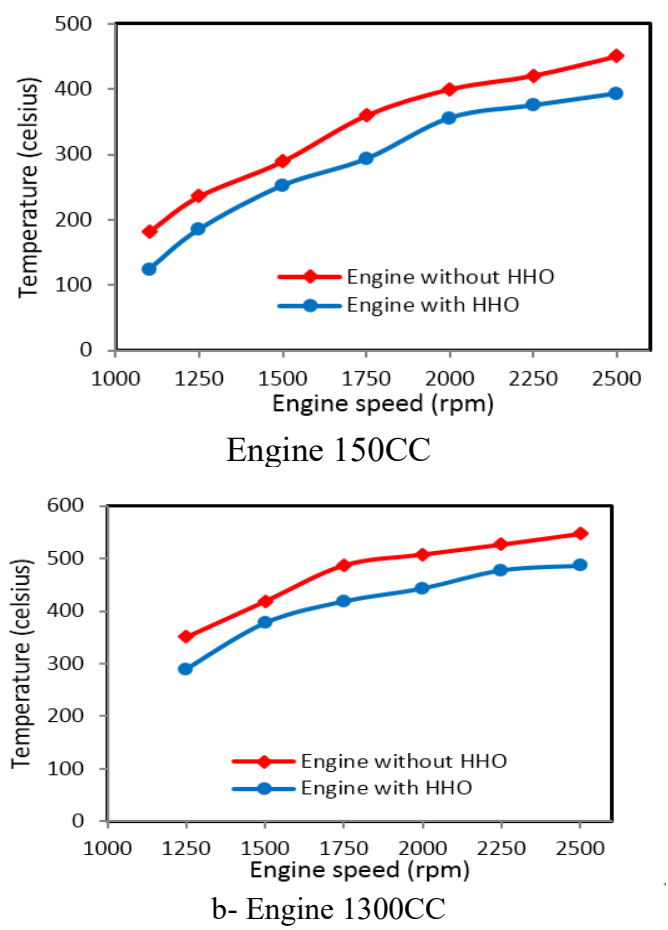

Figure 10. Exhaust gas temperature $\left({ }^{\circ} \mathrm{C}\right)$ versus engine speed (rpm) with and without $\mathrm{HHO}$

With the same previous steps, many real tests and trials with different HHO generators, measurements and different engines performance evaluation are performed experimentally on different internal combustion engines. All experimental results are recorded and adapted to increase the engines performance. The results were promising and depend on the engine year model and driver behavior as shown in Table 3.

Table 3. Reduction percentage of fuel consumption of different engines

\begin{tabular}{cccc}
\hline Engine model & $\begin{array}{c}\text { Engine } \\
\text { size (CC) }\end{array}$ & $\begin{array}{c}\text { Year } \\
\text { model }\end{array}$ & $\begin{array}{c}\text { Saving fuel } \\
\text { consumption (\%) }\end{array}$ \\
\hline Renault Duster & 1800 & 2001 & 27 \\
Jeep Sheroky & 3700 & 2011 & 30 \\
$\begin{array}{c}\text { Daewoo } \\
\text { Nubira }\end{array}$ & 1600 & 1998 & 21 \\
$\begin{array}{c}\text { Chevrolet } \\
\text { Lanos }\end{array}$ & 1500 & 2003 & 18 \\
$\begin{array}{c}\text { Suzuki } \\
\text { (carburetor) }\end{array}$ & 1000 & 2013 & 20 \\
generator & $500 \mathrm{kw}$ & - & 18 \\
\hline
\end{tabular}




\subsection{Engine gas emissions}

The exhaust gases are analyzed using gas analyzer for engines without and with $\mathrm{HHO}$ gas. The results indicate a reduction in gas emissions for engines with $\mathrm{HHO}$ gas. HORIBA automotive emission analyzer MX-002 (MEXA$324 \mathrm{~J}$ ) is an emission gas analyzer device used to measure the concentrations of $\mathrm{CO}$ and $\mathrm{HC}$ in the engine exhaust gases. The gas analyzer readings are shown in Table 4 . That records $\mathrm{CO}$ and $\mathrm{HC}$ readings for $150 \mathrm{CC}$ and $1300 \mathrm{CC}$ engines with and without $\mathrm{HHO}$ gas.

Table 4. Gas analyzer readings of $\mathrm{CO}$ and $\mathrm{HC}$ emission gases

\begin{tabular}{cccc}
\hline Emission & $\begin{array}{c}\text { without } \\
\text { HHO }\end{array}$ & $\begin{array}{c}\text { woCC engine } \\
\text { with HHO }\end{array}$ & $\begin{array}{c}\text { Reduction } \\
\text { percent \% }\end{array}$ \\
\hline CO & $2.45 \%$ & $1.64 \%$ & $33 \%$ \\
HC & $985 \mathrm{ppm}$ & 674 & $27.4 \%$ \\
& & $1300 \mathrm{CC}$ engine & \\
Emission & without & with HHO & $\begin{array}{c}\text { Reduction } \\
\text { percent \% }\end{array}$ \\
& HHO & $0.43 \%$ & $24.5 \%$ \\
$\mathrm{HC}$ & $0.57 \%$ & $142 \mathrm{ppm}$ & $21 \%$ \\
\hline
\end{tabular}

As carbon monoxide emission was affected by the engine combustion efficiency and the Air/fuel ratio. So, the utilization of HHO gas with interior oxygen content enriches the engine combustion process and decreases the percentage of $\mathrm{CO}$ in the exhaust gases as shown in Figure 11. The reduction in $\mathrm{CO}$ percentage for $150 \mathrm{CC}$ and $1300 \mathrm{CC}$ using $\mathrm{HHO}$ gas with engines are $33 \%$ and $24.5 \%$ respectively.
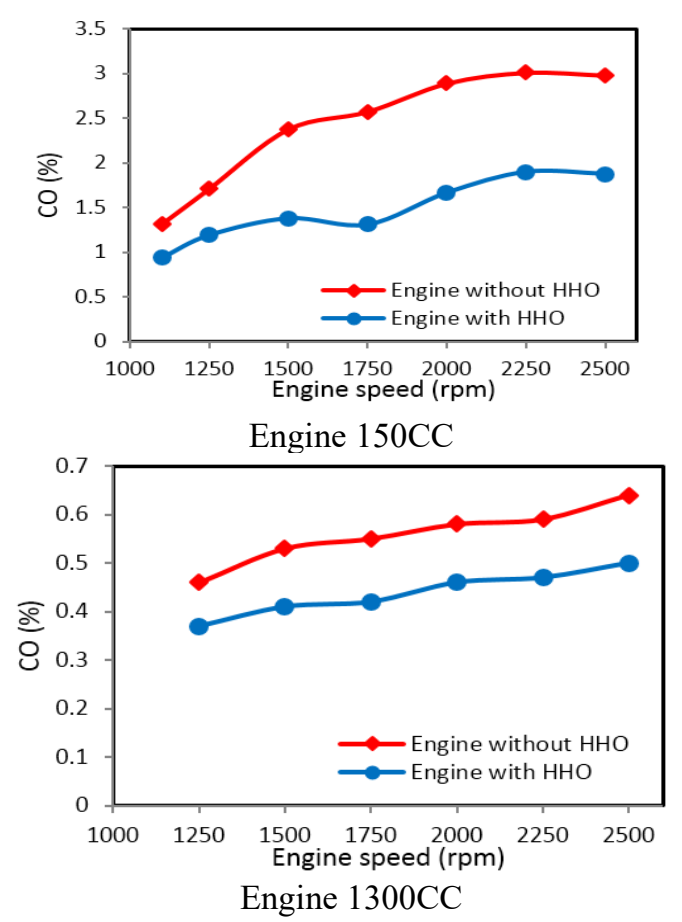

Figure 11. Carbon monoxide concentration (\%) versus engine speed (rpm) with and without $\mathrm{HHO}$

The diatomic and magnecular bonds in HHO gas atomic structure with high start response without propagation delay of ignition owing to reaction surface travel time ensures complete and efficient fuel burning and results in the reduction of emission percentages.

The unburned fuel, means hydrocarbons (HC), emitted with emission gases due to the incomplete burning. Figure 12 shows HC is decreased as the engine speed is increased. HC percentage for engines blending $\mathrm{HHO}$ gas with air and fuel mixture was lower than the conventional engines. $\mathrm{HC}$ is decreased due to the increase of the fuel oxidation; as oxygen is already exist with sensible percentage in HHO gas, which results in fewer quenching distance, wide-ranging flammability and high combustion efficiency. The reduction in $\mathrm{HC}$ percentage for $150 \mathrm{CC}$ and $1300 \mathrm{CC}$ with using $\mathrm{HHO}$ gas are $27.4 \%$ and $21 \%$ respectively. By comparison with earlier works [29 \& 30] have the same engine volume but different models, and approximately at the same test conditions, the present work for $150 \mathrm{CC}$ shows greater reduction in fuel consumption and gas emissions but for 1300CC lower reduction in fuel consumption and higher reduction in gas emission.
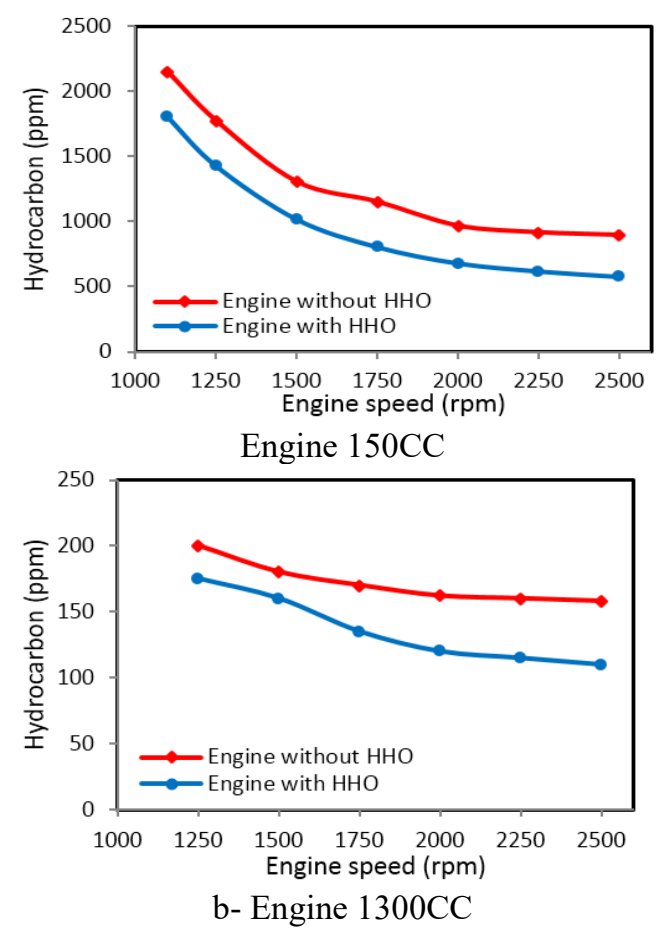

Figure 12. Hydrocarbons concentration (ppm) versus engine speed (rpm) with and without HHO

\subsection{Experimental error and uncertainty analysis}

The accuracy of the measured data must be analyzed to validate the results. After devices calibration, the measured errors decrease to small values and acceptable range. The uncertainty analysis can be calculated and depends on the error of direct measured data [29, 41]. Engine power uncertainty $\left(U_{E P}\right)$ depends on engine speed and engine load errors ( $U_{E S}$ and $\mathrm{U}_{\mathrm{EL}}$ ) however $\mathrm{HHO}$ cell power uncertainty $\left(\mathrm{U}_{\mathrm{CP}}\right)$ depends on voltage and amperage errors ( $\mathrm{U}_{\mathrm{V}}$ and $\mathrm{U}_{\mathrm{I}}$ ) at maximum and minimum operating conditions as shown in table 5 .

$\mathrm{U}_{\mathrm{P}}=\sqrt{\left(\frac{\partial \mathrm{P}}{\partial \mathrm{x}} \times \mathrm{U}_{\mathrm{x}}\right)^{2}+\left(\frac{\partial \mathrm{P}}{\partial \mathrm{y}} \times \mathrm{U}_{\mathrm{y}}\right)^{2}}$ 
Table 5. Uncertainty analysis

\begin{tabular}{cccccc}
\hline Item & $\begin{array}{c}\text { Engine speed } \\
(\mathbf{r p m})\end{array}$ & $\begin{array}{c}\text { Engine speed error } \\
\left(\mathbf{U}_{\mathbf{E S}}\right)\end{array}$ & $\begin{array}{c}\text { Engine load } \\
(\mathbf{N})\end{array}$ & $\begin{array}{c}\text { Engine load error } \\
\left(\mathbf{U}_{\mathbf{E L})}\right)\end{array}$ & $\begin{array}{c}\text { Engine power uncertainty } \\
\left(\mathbf{U}_{\mathbf{E P}}\right)\end{array}$ \\
\hline $\begin{array}{c}\text { Maximum engine } \\
\text { conditions }\end{array}$ & 2500 & \pm 50 & 100 & \pm 1 & \pm 0.41 \\
Minimum engine conditions & 1100 & \pm 50 & 20 & \pm 1 & \pm 0.12 \\
Item & $\begin{array}{c}\text { Cell current } \\
(\mathrm{A})\end{array}$ & $\begin{array}{c}\text { Cell current error } \\
\left(\mathrm{U}_{\mathrm{I}}\right)\end{array}$ & $\begin{array}{c}\text { Cell voltage } \\
\text { (V) }\end{array}$ & $\begin{array}{c}\text { Cell voltage error } \\
\text { (UV) }\end{array}$ & $\begin{array}{c}\text { Cell power uncertainty } \\
\left(\mathrm{U}_{\mathrm{CP}}\right)\end{array}$ \\
$\begin{array}{c}\text { Maximum HHO cell } \\
\text { conditions }\end{array}$ & 11 & \pm 0.02 & 14.1 & \pm 0.01 & \pm 0.178 \\
$\begin{array}{c}\text { Minimum HHO cell } \\
\text { conditions }\end{array}$ & 4 & \pm 0.02 & 12 & \pm 0.01 & \pm 0.126 \\
\hline
\end{tabular}

\section{CONCLUSION}

Oxy-hydrogen gas can be generated from dry cell by electrolysis process of water with $\mathrm{NaOH}$ as a catalyst. $\mathrm{HHO}$ gas has several advantages and several applications. Decreasing the fuel consumption and the environmental pollution are considered the main factors of using HHO gas especially in recent years since the fossil fuel is sever depleted and the environment is highly polluted. Many types of HHO dry generators were designed, fabricated, and tested. HHO gas has different applications in transportation, desalination, cooking, welding and cutting. Vehicles were considered a promising application of $\mathrm{HHO}$ gas, so two engines are tested 150CC and 1300CC (old and new engines). Results showed reduction $14.8 \%$ and $16.3 \%$ in fuel consumption, $33 \%$ and $24.5 \%$ reduction in $\mathrm{CO}, 27.4 \%$ and $21 \%$ reduction in $\mathrm{HC}$ and obvious reduction in the exhaust gases temperature for $150 \mathrm{CC}$ and $1300 \mathrm{CC}$ engines respectively. Also, $17.9 \%$ and $22.4 \%$ increase in brake power and $15.7 \%$ and $22.4 \%$ increase in thermal efficiency were recorded for $150 \mathrm{CC}$ and $1300 \mathrm{CC}$ respectively.

Multi-media content: This link shows the videos of all studied experimental tests: https://youtu.be/9VrXVaomFgM

\section{REFERENCES}

[1] Manieniyan V, Thambidurai M, Selvakumar R. (2009). Study on energy crisis and the future of fossil fuels. Proceedings of SHEE, Engineering Wing, DDE, Annamalai

University. http://dx.doi.org/10.13140/2.1.2234.3689

[2] Öztürk S, Sözdemir A, Ülger Ö. (2013). The real crisis waiting for the world: Oil problem and energy security. International Journal of Energy Economics and Policy 3: 74-79.

[3] Höök M, Tang X. (2013). Depletion of fossil fuels and anthropogenic climate change: A review. Energy Policy 52 :

797-809. https://doi.org/10.1016/j.enpol.2012.10.046

[4] Mohamed W. (2015). Variability in vehicle exhaust emissions and fuel consumption in urban driving pattern. American Journal of Vehicle Design 3(1): 31-38. http://dx.doi.org/10.12691/ajvd-3-1-5

[5] McCartney G, Hanlon P, Romanes F. (2008). Climate change and rising energy costs will change everything: a new mindset and action plan for 21 st century public health. Public Health 122(7): 658-663. http://dx.doi.org/10.1016/j.puhe.2008.03.018

[6] Zecca A, Chiari L. (2010). Fossil-fuel constraints on global warming. Energy Policy 38(1): 1-3. https://doi.org/10.1016/j.enpol.2009.06.068

[7] Piotr B, Joseph W, Andrzej S, Piotr P. (2015). The impact of alternative fuels on fuel consumption and exhaust emissions of greenhouse gases from vehicles featuring si engines. 12th International Conference on Combustion \& Energy Utilisation. Energy Procedia 66: 21-24. https://doi.org/10.1016/j.egypro.2015.02.011

[8] Li L, Ge Y, Wang M, Li J, Peng Z, Song Y, Zhang L. (2016). Effect of gasoline/methanol blends on motorcycle emissions: Exhaust and evaporative emissions. Atmospheric Environment 102: 79-85. https://doi.org/10.1016/j.atmosenv.2014.11.044

[9] Chen RH, Chiang LB, Wu MH, Lin TH. (2010). Gasoline displacement and NOx reduction in an SI engine by aqueous alcohol injection. Fuel 89: 604-610. https://doi.org/10.1016/j.fuel.2009.07.015

[10] Turner D, Xu H, Cracknell RF, Natarajan V, Chen X. (2011). Combustion performance of bio-ethanol at various blend ratios in a gasoline direct injection engine. Fuel 90: 1999-2006. https://doi.org/10.1016/j.fuel.2010.12.025

[11] Karagoz Y, Yuka N, Sandalci T, Dalkılıc AS. (2015). Effect of hydrogen and oxygen addition as a mixture on emissions and performance characteristics of a gasoline engine. International Journal of Hydrogen Energy 40: 8750-8760

http://dx.doi.org/10.1016/j.ijhydene.2015.05.039

[12] Al-Baghdadi MA, Al-Janabi HA. (2000). Improvement of performance and reduction of pollutant emission of a four stroke spark ignition engine fueled with hydrogengasoline fuel mixture. Energy Conversion and Management 41(1): 77-91. http://dx.doi.org/10.1016/S0196-8904(99)00080-1

[13] Ji C, Wang S. (2009). Effect of hydrogen addition on combustion and emissions performance of a spark ignition gasoline engine at lean conditions. International Journal of Hydrogen Energy 34(18): 7823-7834. http://dx.doi.org/10.1016/j.ijhydene.2009.06.082

[14] Shah SAQ, Ali Z, Larik J, Kaimkhani AA. (2018). Comparative study of dry cell and wet cell for the HHO gas generation as a supplement fuel for I.C. engine. International Conference on Computing, Mathematics and Engineering Technologies Pakistan. http://dx.doi.org/10.1109/ICOMET.2018.8346422

[15] Egan DR, León DCP, Wood RJ, Jones RL, Stokes KR., Walsh FC. (2013). Developments in electrode materials and electrolytes for aluminium-air batteries. Journal of Power Sources 236: 293-310. https://doi.org/10.1016/j.jpowsour.2013.01.141 
[16] Salem RR. (2008). Theory of the electrolysis of water. Protection of Metals and Physical Chemistry of Surfaces 44(2):

$120-125$. http://dx.doi.org/10.1134/S0033173208020021

[17] Mamilla VR, Murthy KS, Krishna MV, Swamy TS, Ramesh A, Krishna MU. (2018). Production of Brown's gas using hydroxy generator. International Journal of Engineering \& Technology 7(4.5): 428-457. http://dx.doi.org/10.14419/ijet.v7i4.5.20198

[18] Vino VJ, Ramanlal VS, Madhusudhan Y. (2012). Performance analysis of Petrol-HHO Engine. MiddleEast Journal of Scientific Research 12(12): 1634-1637. http://dx.doi.org/10.5829/idosi.mejsr.2012.12.12.44

[19] Abhilash R, Gopalakrishna K, Venkatesh K. (2015). Performance evaluation of an IC engine using oxyhydrogen as a fuel supplement. Journal of Scientific \& Industrial Research 74(3): 176-179.

[20] Shashikant J, Gabhane D, Deshmukh SS. (2015). Investigating the effect of Oxy-Hydrogen (HHO) gas and Gasoline Blend Addition on the performance of constant speed internal combustion engines. International Engineering Research Journal 26-31.

[21] Sakhrieh AH, Al-Hares AN, Faqes FA, Al-Baqain AS, Alrafie NH. (2017). Optimization of oxyhydrogen gas flow rate as a supplementary fuel in compression ignition combustion engines. International Journal of Heat and Technology 35(1): 116-122. http://dx.doi.org/10.18280/ijht.350116

[22] Chauhan BV, Rathod GP, Patel TM. (2016). An experimental investigation of $\mathrm{HHO}$ gas and varying compression ratio on performance characteristics of constant speed diesel engine. Journal of Mechanical and $\begin{array}{lll}\text { Civil } & \text { Engineering } & \text { 41-47 }\end{array}$ http://dx.doi.org/10.9790/1684-1302034147

[23] Ragupathy K. (2017). Modeling and analysis of diesel engine with addition of hydrogen-hydrogen-oxygen gas. Thermal Science 21(2): 465-471. http://dx.doi.org/10.2298/TSCI17S2465R

[24] Pawar P, Baheti P, Darade S, Menghani PD. (2017). Performance analysis of gasoline engine by addition of $\mathrm{HHO}$ gas as a secondary fuel. International Conference on Ideas, Impact and Innovation in Mechanical Engineering 5(6): 2321-8169.

[25] Govind B, Siva SNV, Kumar BR, Upendar S. (2015). Optimal performance and Analysis on 4-S Si and CI Engine Fueled with HHO Gas and LPG Enriched Gasoline. Journal of Mechanical and Civil Engineering 12(6): 44-51. http://dx.doi.org/10.9790/1684-12644451

[26] Wang S, Ji C, Zhang B, Liu X. (2012). Performance of a hydroxygen blended gasoline engine at different hydrogen volume fractions in the hydroxygen. International Journal of Hydrogen Energy 37: 1320913218. http://dx.doi.org/10.1016/j.ijhydene.2012.03.072

[27] Mahendran M, Revanth S, Kumar MS, Karthik RS (2018). Review of performance and emission characteristics of $\mathrm{HHO}$ Gas as a fuel. International Journal of Research in Engineering, Science and Management 1(11): 420-423.

[28] Wang S, Ji C, Zhang J, Zhang B. (2011). Improving the performance of a gasoline engine with the addition of hydrogen-oxygen mixtures. International journal of hydrogen energy 36: 11164-11173. http://dx.doi.org/10.1016/j.ijhydene.2011.05.138

[29] EL-Kassaby MM, Eldrainy YA, Khidr ME, Khidr KI. (2016). Effect of hydroxy (HHO) gas addition on gasoline engine performance and emissions. Alexandria Engineering Journal 55: 243-251. http://dx.doi.org/10.1016/j.aej.2015.10.016

[30] Krishna VM. (2018). Emissions control and performance evaluation of spark ignition engine with oxy-hydrogen blending. International Journal of Heat and Technology 36(1): 118-124. https://doi.org/10.18280/ijht.360116

[31] Rajasekaran T, Duraiswamy K, Bharathiraja M, Poovaragavan S. (2015). Characteristics of engine at various speed conditions by mixing of $\mathrm{HHO}$ with gasoline and LPG. Journal of Engineering and Applied Sciences 10(1): 46-51.

[32] Sunil RM, Ramakrishna A, Naveen KP. (2014). Modification of SI engine to $\mathrm{HHO}$ engine using $\mathrm{HHO}$ generator and its analysis. International Journal of Mechanical Engineering and Computer Applications 2(2): 50-58.

[33] Musmar SA, Al-Rousan AA. (2011). Effect of HHO gas on combustion emissions in gasoline engines. Fuel 90: 3066-3070. http://dx.doi.org/10.1016/j.fuel.2011.05.013

[34] Al-Rousan AA. (2010). Reduction of fuel consumption in gasoline engines by introducing $\mathrm{HHO}$ gas into intake manifold. international journal of hydrogen energy 35 : 12930-35. http://dx.doi.org/10.1016/j.ijhydene.2010.08.144

[35] Yilmaz AC, Uludamar E, Aydin K. (2010). Effect of hydroxy (HHO) gas addition on performance and exhaust emissions in compression ignition engines, International Journal of Hydrogen Energy 35: 1136611372. http://dx.doi.org/10.1016/j.ijhydene.2010.07.040

[36] Karagöz Y. (2018). Effect of hydrogen addition at different levels on emissions and performance of a diesel engine. Journal of Thermal Engineering 4(2): 1780-1790. http://dx.doi.org/10.18186/journal-of-thermalengineering. 372968

[37] Wiseman G. (2008). Brown's Gas, Book Two. Build a high quality Browns Gas electrolyze that will exceed the performance of ANY known commercial machine to date. 2000, Canada.

[38] HHO Hydrogen Generator Dry Cell Installation Manual Instructions Presented by LaBella's Auto Repair. http://labellasautorepair.com.

[39] Streblau M, Aprahamian B, Simov M, Dimova T. (2014). The influence of the electrolyte parameters on the efficiency of the oxyhydrogen (HHO) generator. 18th International Symposium on Electrical Apparatus and Technologies. http://dx.doi.org/10.1109/SIELA.2014.6871898

[40] Santilli RM. (2006). A new gaseous and combustible form of water. International Journal of Hydrogen Energy 31(9): $1113-1128$ http://dx.doi.org/10.1016/j.ijhydene.2005.11.006

[41] Barford NC, Richards JW, (1990). Experimental measurements: Precision, error and truth and interpretation of technical data. John Wiley \& Sons, New York. https://physicstoday.scitation.org/doi/10.1063/1.303533 3 